\title{
Field data and prediction models of pesticide spray drift on coffee crop
}

\author{
Guilherme Sousa Alves( ${ }^{(1)}$ and João Paulo Arantes Rodrigues da Cunha(1)
}

(1)Universidade Federal de Uberlândia, Instituto de Ciências Agrárias, Campus Umuarama, Caixa Postal 593, CEP 38400-902 Uberlândia, MG, Brazil. E-mail: guilhermeagro43@yahoo.com.br, jpcunha@iciag.ufu.br

\begin{abstract}
The objective of this work was to generate drift curves from pesticide applications on coffee plants and to compare them with two European drift-prediction models. The used methodology is based on the ISO 22866 standard. The experimental design was a randomized complete block with ten replicates in a 2x20 split-plot arrangement. The evaluated factors were: two types of nozzles (hollow cone with and without air induction) and 20 parallel distances to the crop line outside of the target area, spaced at $2.5 \mathrm{~m}$. Blotting papers were used as a target and placed in each of the evaluated distances. The spray solution was composed of water+rhodamine B fluorescent tracer at a concentration of $100 \mathrm{mg} \mathrm{L}^{-1}$, for detection by fluorimetry. A spray volume of $400 \mathrm{~L} \mathrm{ha}^{-1}$ was applied using a hydropneumatic sprayer. The air-induction nozzle reduces the drift up to $20 \mathrm{~m}$ from the treated area. The application with the hollow cone nozzle results in $6.68 \%$ maximum drift in the nearest collector of the treated area. The German and Dutch models overestimate the drift at distances closest to the crop, although the Dutch model more closely approximates the drift curves generated by both spray nozzles.
\end{abstract}

Index terms: Coffea arabica, drift curves, environmental contamination, hydropneumatic sprayer, nozzles.

\section{Dados de campo e modelos de estimação de deriva nas aplicações de agrotóxicos na cultura do café}

\begin{abstract}
Resumo - O objetivo deste trabalho foi gerar curvas de deriva a partir de aplicações de agrotóxicos em cafeeiro e compará-las a dois modelos europeus de simulação de deriva. A metodologia utilizada baseia-se na norma ISO 22866. Utilizou-se o delineamento experimental de blocos ao acaso, com dez repetições, em arranjo fatorial $2 \times 20$ com parcelas subdivididas. Os fatores avaliados foram: dois tipos de pontas de pulverização (cone vazio com e sem indução de ar) e 20 distâncias paralelas à linha de cultivo fora da área-alvo, espaçadas em $2,5 \mathrm{~m}$. Foram colocados papéis filtrantes como alvo, em cada uma das distância avaliadas. A calda foi composta por água+corante fluorescente rodamina $\mathrm{B}$ na concentração de $100 \mathrm{mg} \mathrm{L}^{-1}$, para detecção por fluorimetria. Aplicou-se volume de calda de $400 \mathrm{~L} \mathrm{ha}^{-1}$, por pulverizador hidropneumático. A ponta com indução de ar reduz a deriva até $20 \mathrm{~m}$ de distância da área tratada. A aplicação com ponta de jato cônico resulta em deriva máxima de 6,68\% no ponto de coleta mais próximo da área tratada. Os modelos Alemão e Holandês superestimam a deriva nas distâncias mais próximas à cultura, embora o modelo Holandês se aproxime mais das curvas de deriva geradas por ambas as pontas de pulverização.
\end{abstract}

Termos para indexação: Coffea arabica, curvas de deriva, contaminação ambiental, pulverizador hidropneumático, pontas de pulverização.

\section{Introduction}

Coffee (Coffea arabica L.) production represents an important agricultural activity in South America, and Brazil is the world's largest coffee producer and exporter (Companhia Nacional de Abastecimento, 2013). The crop is subject to attack by several pests and diseases that, in many cases, require chemical control. However, there is little information about technology for the application of insecticides and fungicides on coffee. Knowledge of the performance of pesticide-spraying equipment is fundamental for appropriate application, ensuring both biological efficacy and environmental safety (Cunha, 2008).

The type of spray nozzle and its working characteristics are some of the main factors that affect losses of pesticides to the environment. Hollow cone nozzles are traditionally recommended for applications on crops with broad leaf mass, in which penetration and coverage are essential. These nozzles produce very small droplets with a high risk of drift. Spray drift is defined as the quantity of plant protection product carried out of the sprayed (treated) area by air currents during application. It persists as one of the major 
problems in modern agriculture (Tsai et al., 2005; Nuyttens et al., 2011).

Due to this risk, an air-induction variant of this nozzle, which produces droplets of a larger diameter, was released onto the market (Figueroa et al., 2012). By producing large to extremely large droplets, these nozzles have reduced risks of drift. Therefore, some producers envision the possibility of substituting hollow cone nozzles with other more environmentally safe ones, as long as the nozzles do not compromise the efficacy of the application.

Research on drift aims to determine the appropriate measures to minimize the negative effects of spray application on the environment (Baetens et al., 2009). In this sense, some prediction models have been developed to evaluate drift (Lebeau et al., 2011). The most commonly used model worldwide was created in the 1990s in Germany (Ganzelmeier et al., 1995). However, it is not known whether these models can be applied in tropical conditions, since they were developed for important plants in the European climate.

In some countries, one solution to reduce pesticide drift was to establish buffer zones, stipulated by drift-prediction models associated with toxicological studies (De Schampheleire et al., 2007). These zones involve rows of vegetation that cannot receive the application of pesticides, in order to avoid contamination of a specific sensitive area, such as water course regions.

However, the size of the buffer zone is variable and depends on the application conditions. Therefore, it is necessary to study the horizontal distance that a droplet can travel under different operational spraying conditions, for the establishment of buffer zones with the correct size and for more effective and environmentally safe applications.

Despite the environmental risk from pesticides, few studies assess pesticide drift in coffee production, especially under tropical conditions.

The objective of this work was to generate drift curves from pesticide applications on coffee plants and to compare them with two European drift-prediction models.

\section{Materials and Methods}

The experiment was performed at the Coffee Production Sector of Universidade Federal de

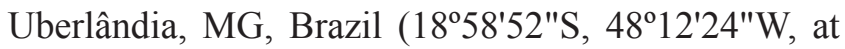
an average altitude of $912 \mathrm{~m}$ ).
For pesticide applications, a Arbo 360 hydropneumatic airblast sprayer was used (Montana, São José dos Pinhais, PR, Brazil), with 12 nozzles (six on each side) coupled to the hydraulic system of a 265E Massey Ferguson tractor (Massey Ferguson, Itu, São Paulo, Brazil). Two hollow-cone jet nozzles with and without air induction, respectively, were evaluated: ATR $80^{\circ}$ Orange 3.0 nozzle (Albuz, Gravigny, France), with traditional application; and TVI 8002 nozzle (Albuz, Gravigny, France), using low-drift application.

A spray volume of $400 \mathrm{~L} \mathrm{ha}^{-1}$ was used. The displacement velocity of the machine was $8.2 \mathrm{~km} \mathrm{~h}^{-1}$. The working pressures for the ATR and TVI spray nozzles were $1.567 \mathrm{MPa}\left(227.5 \mathrm{lb} \mathrm{in}^{-2}\right)$ and $1.447 \mathrm{MPa}(210$ $\left.1 \mathrm{~b} \mathrm{in}{ }^{-2}\right)$, respectively. According to the manufacturer, at these pressures, the ATR and TVI nozzles produce very fine (lower than $100 \mu \mathrm{m}$ ) and very course (between 375 and $450 \mu \mathrm{m})$ droplets, respectively. The manufacturer used the ASAE S-572 standard to classify the volume median diameter.

Prior to the applications, the sprayer was calibrated by determining the flow rate from each nozzle; then, the best angle for the nozzles, along with the arc of the sprayer, was determined using a patternator to reduce the loss of spray above the crop canopy and to prevent the jet formed by the lowest nozzles of the arc from spraying directly into the soil. The coefficients of variation $(\mathrm{CV})$ for the flow rates from the ATR and TVI nozzles were 3.99 and $6.40 \%$, respectively. Wolf \& Smith (1979) concluded that a CV less than $15 \%$ is desirable.

The air flow rate from the fan was determined using air velocity and outlet area, according to the methodology proposed by Rodrigues et al. (2008). The flow rate from the left side was $1.64 \mathrm{~m}^{3} \mathrm{~s}^{-1}$ and from the right side was $1.58 \mathrm{~m}^{3} \mathrm{~s}^{-1}$.

For the drift study, a rhodamine B tracer was used (Synth, Diadema, SP, Brazil) at a concentration of $100 \mathrm{mg} \mathrm{L}^{-1}$, added to the spray for later quantification by fluorimetry.

The applications were conducted in an area planted with 'Catuaí Vermelho' coffee spaced at $3.8 \mathrm{~m}$ between lines and $0.7 \mathrm{~m}$ between plants of three years of age and average height of $2.5 \mathrm{~m}$. The average lower diameter of the tree crown was $1.2 \mathrm{~m}$. The leaf area index (LAI) of the coffee plant was estimated indirectly through measurements of the lower diameter and the height of the crown, following Favarin et al. (2002). The estimated LAI was 4.38 .

Pesq. agropec. bras., Brasília, v.49, n.8, p.622-629, ago. 2014 DOI: $10.1590 / \mathrm{S} 0100-204 X 2014000800006$ 
The experimental design was a randomized complete block with ten replicates in a $2 \times 20$ split-plot arrangement in space. Two factors were evaluated: two spray nozzles - standard and air-induction hollow cone; and 20 distances in relation to the last line sprayed.

The drift to the soil was determined according to the ISO 22866 standard (International Organization for Standardization, 2005). Prior to the applications, polyethylene plates with dimensions of $0.40 \mathrm{x} 0.08 \mathrm{x}$ $0.006 \mathrm{~m}$ were placed at ground level in an area adjacent to the crop outside of the target area, perpendicular to the direction of the sprayer application and in the main direction of the wind (downwind). The plates, spaced at $2.5 \mathrm{~m}$ from each other, were placed at a distance of $2.5 \mathrm{~m}$ from the center of the last spray application up to $50 \mathrm{~m}$, totaling 20 distances in relation to the last line sprayed. This same arrangement was repeated in four lines spaced at $1.5 \mathrm{~m}$ from each other, perpendicular to the direction of the displacement of the sprayer.

For statistical analysis, the average from these four collectors was used for each distance. The four lines of plants adjacent to the drift-evaluation area were sprayed, for a total length of $50 \mathrm{~m}$, constituting one replicate. On the last spray of the equipment, only the side of the sprayer arc aimed toward the lines of coffee plants was used. Each application during one replicate took approximately $3 \mathrm{~min}$.
Blotting papers (J. Prolab, Ind. e Comércio de Produtos para Laboratório Ltda., São José dos Pinhais, $\mathrm{PR}$, Brazil) with a neutral $\mathrm{pH}, 65 \mathrm{~g} \mathrm{~m}^{-2}$ of weight, and dimensions of $0.38 \times 0.07 \mathrm{~m}$ were fixed onto the polyethylene plates.

Once the application was performed, the papers were collected and placed in a heat- and light-insulated container. The samples were kept in a refrigerator at $10^{\circ} \mathrm{C}$ in a laboratory until the end of the field data collection.

Meteorological conditions were monitored during the applications, including velocity and direction of the wind, temperature and relative humidity of the air. For this analysis, a meteorological station with automatic data acquisition was used, installed next to the experimental area. Data acquisition was conducted targeting temperatures between 5 and $35^{\circ} \mathrm{C}$, wind speeds between 1 and $5 \mathrm{~m} \mathrm{~s}^{-1}$, and wind direction within a limit of $90 \pm 30^{\circ}$ from the spray line and in the direction of the sampling area. There were no specifications for the relative humidity of the air in the ISO standard. In all of the applications, the wind direction was within the range of angles permitted by the ISO 22866 standard. The temperature and wind velocity also met the standard (Table 1).

In the laboratory, rhodamine B was extracted from the blotting papers according to Scramin et al. (2002).

Table 1. Date and hour of meteorological conditions during pesticide spraying on coffee (Coffea arabica) crop to evaluate drift caused by hollow cone nozzles with (ATR) and without air induction (TVI).

\begin{tabular}{|c|c|c|c|c|c|c|c|}
\hline Replicate & Nozzle & Date & Hour & $\begin{array}{c}\text { Temperature } \\
\left({ }^{\circ} \mathrm{C}\right)\end{array}$ & $\begin{array}{c}\text { Relative humidity } \\
\text { of air (\%) }\end{array}$ & $\begin{array}{l}\text { Wind velocity } \\
\left(\mathrm{m} \mathrm{s}^{-1}\right)\end{array}$ & $\begin{array}{c}\text { Wind } \\
\text { direction }\end{array}$ \\
\hline \multirow{2}{*}{1} & ATR & \multirow{2}{*}{$4 / 17 / 2013$} & 09:01 & 19.7 & 71 & 0.83 & ESE \\
\hline & TVI & & 09:39 & 20.5 & 66 & 0.83 & ESE \\
\hline \multirow{2}{*}{2} & ATR & \multirow{2}{*}{$4 / 17 / 2013$} & $15: 33$ & 27.6 & 39 & 2.50 & ESE \\
\hline & TVI & & $16: 04$ & 27.4 & 36 & 2.65 & ESE \\
\hline \multirow{2}{*}{3} & ATR & \multirow{2}{*}{$4 / 18 / 2013$} & 08:52 & 19.6 & 73 & 1.22 & SE \\
\hline & TVI & & $09: 26$ & 21.3 & 74 & 1.00 & SE \\
\hline \multirow{2}{*}{4} & ATR & \multirow{2}{*}{$4 / 18 / 2013$} & 09:52 & 22.7 & 65 & 2.80 & E \\
\hline & TVI & & $10: 10$ & 22.8 & 64 & 2.45 & $\mathrm{E}$ \\
\hline \multirow{2}{*}{5} & TVI & \multirow{2}{*}{$4 / 18 / 2013$} & $10: 30$ & 23.4 & 60 & 2.77 & $\mathrm{E}$ \\
\hline & ATR & & $10: 52$ & 24.7 & 52 & 3.15 & E \\
\hline \multirow{2}{*}{6} & ATR & \multirow{2}{*}{$4 / 19 / 2013$} & $08: 20$ & 19.4 & 82 & 1.90 & E \\
\hline & TVI & & $08: 46$ & 19.4 & 83 & 2.45 & E \\
\hline \multirow{2}{*}{7} & TVI & \multirow{2}{*}{$4 / 19 / 2013$} & 09:11 & 20.4 & 83 & 3.70 & E \\
\hline & ATR & & 09:35 & 22.1 & 78 & 3.35 & E \\
\hline \multirow{2}{*}{8} & ATR & \multirow{2}{*}{$4 / 23 / 2013$} & $08: 15$ & 16.8 & 85 & 4.12 & $\mathrm{E}$ \\
\hline & TVI & & $08: 43$ & 17.2 & 84 & 3.80 & E \\
\hline \multirow{2}{*}{9} & TVI & \multirow{2}{*}{$4 / 23 / 2013$} & 09:10 & 18.9 & 80 & 3.43 & E \\
\hline & ATR & & 09:34 & 19.3 & 75 & 3.80 & E \\
\hline \multirow{2}{*}{10} & ATR & \multirow{2}{*}{$4 / 23 / 2013$} & 09:58 & 20.6 & 73 & 4.33 & ESE \\
\hline & TVI & & $10: 22$ & 22.0 & 66 & 7.13 & ESE \\
\hline
\end{tabular}


A total of $100 \mathrm{~mL}$ of a solution composed of distilled water and Tween 80 - polyoxyethylene sorbitan monooleate - at $0.2 \%$ (Synth, Diadema, SP, Brazil) was added to each plastic bag, which was subjected to constant agitation at 120 rotations per minute for $15 \mathrm{~min}$ on a pendulum shaker TE-240/I model (Tecnal Equipamentos para Laboratórios, Piracicaba, SP, Brazil). The samples were left to rest for $10 \mathrm{~min}$. For tracer quantification, the samples were placed in borosilicate cuvettes with four polished faces for reading in a fluorimeter model FM109515 with a halogen lamp (Thermo Fisher Scientific Inc., Waltham, MA, USA). The excitation and emission wavelength filters were 540 and $585 \eta \mathrm{m}$, respectively.

The tracer deposit per unit area of drift collectors was determined, expressed in microliters per square centimeter $\left.(\mu \mathrm{L} \mathrm{cm})^{-2}\right)$, using the data on rhodamine B concentration extracted from the blotting papers, as well as the spray volume and the real spray concentration. With the deposition data from the collectors, the percentage of drift for each distance was calculated, relating the deposit to the quantity applied to the field.

For analysis of the assumptions for the drift percentage data, the Kolmogorov-Smirnov, Levene, and Tukey tests were applied to analyze the normality of the residuals, homogeneity of the variances, and additivity of the blocks, respectively, using the SPSS statistical software, version 17.0 (SPSS Inc., Chicago, IL, USA). If the assumptions were not met to $1 \%$ probability, the data were transformed using the arc sine of the square root of $\mathrm{x} / 100$ and subjected to a new analysis.

The data were subjected to analysis of variance using the Sisvar statistical software, version 5.3 (Ferreira, 2008). When a significant difference was found, the nozzles were compared to each other for each distance using Tukey's test, at 5\% probability, whereas regression analysis was performed for the distances.

The drift curves obtained for each spray nozzle were compared using the confidence interval of the equation parameters. For this comparison, the data were linearized using the $\log (\mathrm{x})$ function and subjected to regression analysis. The upper and lower limits of each equation parameter were identified, and, if the intervals were not superimposed at the $95 \%$ confidence level, the curves were considered different.
Additionally, the obtained curves were prepared as a function of distance and compared to the curves from the German (Ganzelmeier et al., 1995) and Dutch (Holterman \& Van de Zande, 2003) drift-prediction models using the $90^{\text {th }}$ percentile of the drift data. For the German model, the application to fruit trees with good leafiness (late-fruit application conditions) was considered. For the Dutch model, the application to fruit trees with leaves was considered.

In the German model, the drift values, expressed as a percentage of the application dose, in function of the $\mathrm{z}$ distance downwind the field, were calculated by the equation: \%drift $=A z^{B}$, in which $\mathrm{A}$ and $\mathrm{B}$ are coefficients that depend on the crop and distance. For distances lower than $10.3 \mathrm{~m}$, the coefficients are 60.3960 and -1.2249 , respectively. For distances higher than $10.3 \mathrm{~m}$, they are 210.7000 and -1.7599 , respectively (Ganzelmeier et al., 1995).

In the Dutch model, the drift values, expressed as a percentage of the application dose, in function of the $\mathrm{z}$ distance downwind the field, were calculated by the equation: \%drift $=\mathrm{A}_{0} \mathrm{e}^{-\mathrm{zx} \mathrm{A}_{1}}+\mathrm{B}_{0} \mathrm{e}^{-\mathrm{zx} \mathrm{B}_{1}}$, in which $\mathrm{A}_{0}$, $\mathrm{A}_{1}, \mathrm{~B}_{0}$, and $\mathrm{B}_{1}$ are equal to $48,0.45,2.70$, and 0.091, respectively, for fruit trees in leaf (Holterman \& Van de Zande, 2003).

\section{Results and Discussion}

The applications made on coffee plants with the TVI nozzle caused less drift than those with the ATR nozzle up to $20 \mathrm{~m}$ of distance from the last line sprayed (Table 2). Beyond this distance, there was no difference between the nozzles. Therefore, the TVI nozzle reduced spray drift to the areas closest to the crop.

In some cases, an increase in drift can occur with air-induction nozzles at distances closer to the treated area due to the passage of large droplets through the lower part of the plants. However, in this experiment, the crowns of the plants were near soil surface, which prevented this process from occurring.

Combellack et al. (1996), while evaluating drift potential in a wind tunnel, observed that the air-induction nozzle reduced the risk of drift by $262 \%$ in relation to the same nozzle without air induction.

Therefore, the TVI nozzle may be a good option for spraying when the coffee crop is located near regions where drift must be reduced as much as possible, such 
as neighboring crops that are sensitive to the applied product, water courses, and inhabitable areas. However, in recommending a nozzle, the deposition of spray on the leaves of the crop must be taken into account.

It is important to emphasize that although the TVI nozzle produces very large drops, it results in 5.06\% drift at a distance of $2.5 \mathrm{~m}$, a value considered high, considering the spectrum of the generated droplets. This drift may have been caused by the association between the strong air turbulence from the propellers of the sprayer and the larger mass of the droplets, which may pass directly through the coffee plants through inertia, especially on the second-to-last spray of the sprayer, in areas closest to the last line of plants.

The drift generated by the ATR nozzle was greater than that by the TVI nozzle at a distance from $2.5 \mathrm{~m}$ until $20 \mathrm{~m}$ (Table 2), which was expected because very

Table 2. Drift percentage resulting from pesticide application with standard (ATR) and air-induction (TVI) hollow cone nozzles on coffee (Coffea arabica) plants ${ }^{(1)}$.

\begin{tabular}{|c|c|c|}
\hline \multirow{2}{*}{$\begin{array}{l}\text { Distance from the } \\
\text { treated area }(\mathrm{m})\end{array}$} & \multicolumn{2}{|c|}{ Spray nozzle } \\
\hline & ATR & TVI \\
\hline 2.5 & $6.68 b$ & $5.06 \mathrm{a}$ \\
\hline 5.0 & $2.75 b$ & $1.59 \mathrm{a}$ \\
\hline 7.5 & $1.67 \mathrm{~b}$ & $0.85 \mathrm{a}$ \\
\hline 10.0 & $1.33 \mathrm{~b}$ & $0.63 \mathrm{a}$ \\
\hline 12.5 & $1.03 \mathrm{~b}$ & $0.47 \mathrm{a}$ \\
\hline 15.0 & $0.82 b$ & $0.40 \mathrm{a}$ \\
\hline 17.5 & $0.69 b$ & $0.35 \mathrm{a}$ \\
\hline 20.0 & $0.52 b$ & $0.30 \mathrm{a}$ \\
\hline 22.5 & $0.45 \mathrm{a}$ & $0.29 \mathrm{a}$ \\
\hline 25.0 & $0.41 \mathrm{a}$ & $0.31 \mathrm{a}$ \\
\hline 27.5 & $0.37 \mathrm{a}$ & $0.30 \mathrm{a}$ \\
\hline 30.0 & $0.35 \mathrm{a}$ & $0.29 \mathrm{a}$ \\
\hline 32.5 & $0.33 \mathrm{a}$ & $0.28 \mathrm{a}$ \\
\hline 35.0 & $0.32 \mathrm{a}$ & $0.30 \mathrm{a}$ \\
\hline 37.5 & $0.30 \mathrm{a}$ & $0.30 \mathrm{a}$ \\
\hline 40.0 & $0.30 \mathrm{a}$ & $0.33 \mathrm{a}$ \\
\hline 42.5 & $0.30 \mathrm{a}$ & $0.30 \mathrm{a}$ \\
\hline 45.0 & $0.28 \mathrm{a}$ & $0.31 \mathrm{a}$ \\
\hline 47.5 & $0.29 \mathrm{a}$ & $0.30 \mathrm{a}$ \\
\hline$\underline{50.0}$ & $0.29 \mathrm{a}$ & $0.32 \mathrm{a}$ \\
\hline \multicolumn{3}{|c|}{$\mathrm{F}_{\text {nozzle }}=8.282 * ; \mathrm{F}_{\text {dist }}=108.860^{* *} ; \mathrm{F}_{\text {int }}=2.965^{*}$} \\
\hline \multicolumn{3}{|c|}{ OR: $\mathrm{F}_{\text {Levene }}=23.267 * * ; \mathrm{K}-\mathrm{S}=0.272 * * ; \mathrm{F}_{\text {Tukey }}^{\prime}=858.318^{* *}$} \\
\hline \multicolumn{3}{|c|}{$\mathrm{T}: \mathrm{F}_{\text {Levene }}=13.567 * * ; \mathrm{K}-\mathrm{S}=0.164 * * ; \mathrm{F}_{\text {Tukey }}^{\prime}=351.741^{* *}$} \\
\hline
\end{tabular}

${ }^{(1)}$ Means followed by equal letters, in the rows, do not differ by Tukey's test, at $5 \%$ probability. $F_{\text {nozzle }}, F_{\text {dist }}$, and $F_{\text {int }}$, values of $F$ calculated for nozzle, distance, and interaction, respectively. $\mathrm{F}_{\text {Levene }}, \mathrm{K}-\mathrm{S}$, and $\mathrm{F}_{\text {'Tukey }}$, values of the F statistic for the Levene test, K-S for the Kolmogorov-Smirnov test, and F for Tukey's test for the additivity of the blocks, respectively, which test the assumptions of the original data (OR) and of the data transformed (T) by arc sine $(\mathrm{x} / 100)^{0.5} . * *$ and $*$ Significant at 1 and $5 \%$ probability, respectively. small droplets are more easily carried by the wind. Between 2.5 and $5 \mathrm{~m}$, there was an abrupt drop in the drift caused by both nozzles $-3.45 \%$ for the TVI nozzle and $3.93 \%$ for the ATR nozzle. This change may be explained by the physical barrier imposed by the coffee plants, associated primarily with the good regulation of the angle of the upper nozzles of the sprayer arc. Therefore, the drift in the areas closest to the crop is caused primarily by air flow from the sprayer, while the drift in more distant areas is caused by the atmospheric wind. This reinforces the importance of adequately regulating the spraying equipment, which can reduce drift even during applications under adverse meteorological conditions.

Based on regression analysis, the power model showed good fit to the data for both of the sprayer nozzles, although the $\mathrm{R}^{2}$ for the TVI nozzle was lower than that for the ATR nozzle, which is probably attributed to the difference between the values observed and estimated for the $2.5 \mathrm{~m}$ distance (Figure 1). A power model was selected due to the availability of the German model as a reference (Ganzelmeier et al., 1995).

The largest drift percentages were obtained at the collection point closest to the crop, and the drift decreased as the collection points moved away from the target area. This pattern was also observed by Yarpuz-Bozdogan \& Bozdogan (2009), who obtained largest drift values at a distance of $1 \mathrm{~m}$ from the crop, using an application rate of $200 \mathrm{~L} \mathrm{ha}^{-1}$ on grassland.

Beyond $20 \mathrm{~m}$, the drift percentage was less than $1 \%$. However, this value was not zero at any distance, not even at $50 \mathrm{~m}$, using the air-induction nozzle. This finding may be related to the lower limit of detection of rhodamine B on the fluorimeter. Working with distances greater than $50 \mathrm{~m}$ does not necessarily result in a more complete analysis if the power of detection of the tracer is low enough that such differences cannot be detected.

The A coefficients of the drift curves were between 12.0918 and 19.1333 for the ATR nozzle and between 2.8155 and 9.1434 for the TVI nozzle, whereas the B coefficients were between -1.1491 and -1.0027 for the ATR nozzle and between -1.0007 and -0.6249 for the TVI nozzle. Because there was no superposition of the values for both the A and B coefficients, the curves were considered to be mathematically different. This difference can be better observed in the regions closest 
to the sprayed area. Therefore, it would be interesting if the preparation of drift-prediction models included the nozzle type used in the application, since drift was shown to be dependent on this factor in the present study.

The curves obtained for the ATR and TVI nozzles were compared with the German and Dutch models using the $90^{\text {th }}$ percentile of the drift data resulting from applications on coffee plants (Figure 2). The $90^{\text {th }}$ percentile is a widely used representation in studies of ecological and toxicological risks (Wang \& Rautmann, 2008). According to these authors, a part of the drift, beyond that measured in the field, is omitted due to combination effects, such as the velocity of the wind and agricultural practices. Because the models do not take into consideration all of the effects, the expression of drift in the $90^{\text {th }}$ percentile, used in pesticide records in the European Union, is a way of compensating for these omissions and increasing the safety of the information, especially for recommendations.

The German and Dutch models estimated a drift of 19 and $17 \%$, respectively, for fruit tree crops at $2.5 \mathrm{~m}$ from the last line sprayed, which are values higher than those observed in the present study. At distances greater than $20 \mathrm{~m}$, the drift curves from the nozzles began to have a similar behavior. This similarity allows for the drift data estimated by Ganzelmeier et al. (1995) to be used on coffee trees without suffering large distortions in studies on the risk for residents exposed to pesticide products. The same is expected for the determination of buffer zones. However, in studies that involve smaller

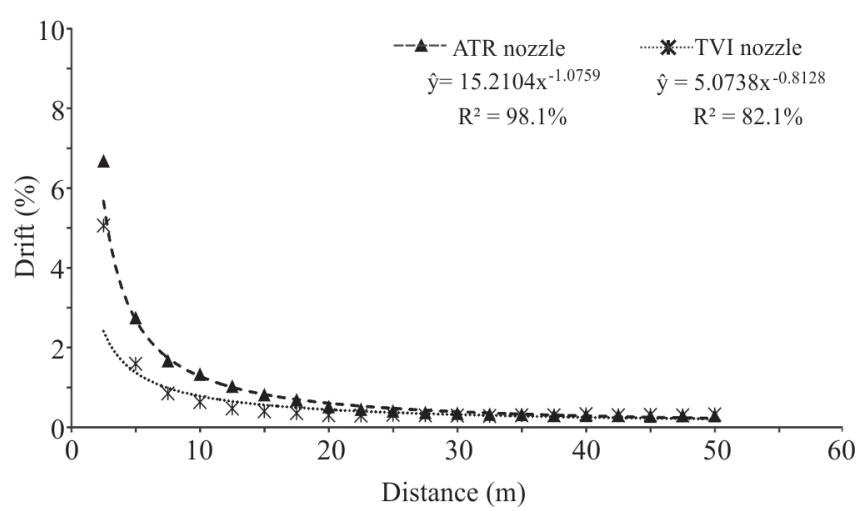

Figure 1. Drift curves from pesticide applications on coffee (Coffea arabica) plants with standard (ATR) and air-induction (TVI) hollow cone spray nozzles. distances, such as those to bystanders, preference must be given to the models developed specifically for coffee.

In the regions closest to the application area (up to $5 \mathrm{~m}$ ), the German model generated the largest drift values, indicating the greatest differences between the data, which can affect the calculation of the total amount of product lost to drift. Therefore, the largest product losses are observed in those regions.

This pattern possibly occurred because regions closest to the treated are the most affected by the spraying process. The coffee plant, in general, is denser than the fruit-bearing crops used in Germany (Ganzelmeier et al., 1995), forming a physical barrier to the passage of the droplets, decreasing the loss of product that passes between the plants of the same line. In the most distant areas from the crop, losses are most likely caused by droplets that pass over the plants, mainly due to the action of the spray fan, and are less influenced by the type of crop.

The German model was prepared based on studies with apple (Malus domestica Borkh.) and pear (Pyrus communis L.) trees, which are crops that differ anatomically and morphologically from coffee. Coffee plant architecture is different from that of most common orchard crops - it is a cylindrically-shaped woody, perennial dicotyledon, with a high leaf area index. Although the Dutch model is considered to be more complete than the German one because it encompasses a larger number of variables, both

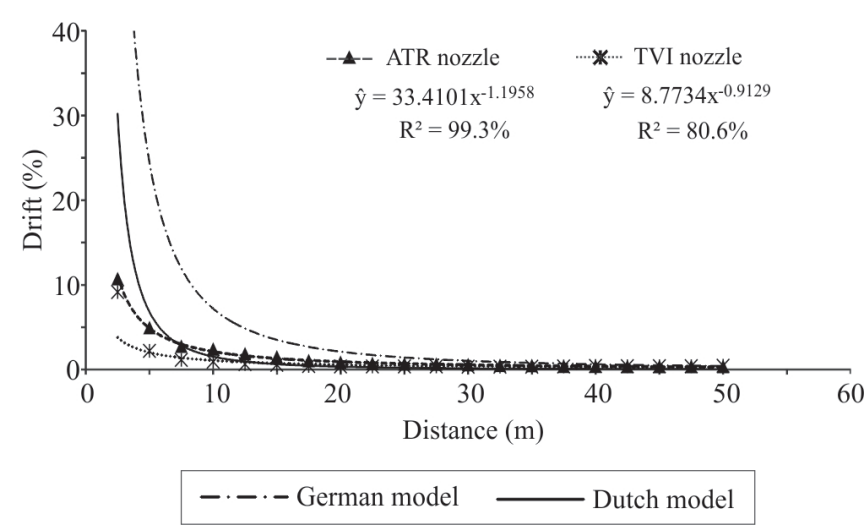

Figure 2. The $90^{\text {th }}$ percentile of the drift percentage from pesticide applications on coffee (Coffea arabica) plants using standard (ATR) and air-induction (TVI) hollow cone nozzles, including a representation of the German and Dutch drift-prediction models for fruit crops.

Pesq. agropec. bras., Brasília, v.49, n.8, p.622-629, ago. 2014 DOI: 10.1590/S0100-204X2014000800006 
models were developed for European conditions of temperate climate and, therefore, must be used with caution to estimate drift in coffee crops in tropical climates. In general, the Dutch model more closely approximated the drift curves obtained in the present study. Furthermore, it is important to note that the physical-chemical properties of the spray mix can change the droplet spectrum and, in this way, affect drift values.

In areas of citrus trees (Citrus spp.) in Italy, the German model overestimated the field data and should not be used for drift prediction in citrus orchards in that region (Meli et al., 2003). Similar results were found by Vischetti et al. (2008), who studied drift-reduction methods in vineyards, comparing a drift-prediction model with field data. The authors concluded that there was agreement between the data only at greater distances, approximately $24 \mathrm{~m}$ from the treated area.

The determination of environmental risk from pesticide application is highly dependent on the drift models employed because they use values that are close to those of the treated areas. This shows the importance of the selection of a drift model, given that evaluations made up to $5 \mathrm{~m}$, to estimate worst-case scenarios, are less accurate than those made at greater distances because of the larger data variability.

\section{Conclusions}

1. The air-induction hollow cone nozzle results in lower drift than the nozzle without air induction, up to $20 \mathrm{~m}$ from the treated area.

2. The application with the hollow cone nozzle results in $6.68 \%$ maximum drift in the nearest collectors of the treated area.

3. The German and Dutch drift-prediction models overestimate the drift at the distances closest to the treated area.

4. The Dutch model more closely approximates the drift curves generated by the hollow cone nozzles, with and without air induction.

\section{Acknowledgement}

To Conselho Nacional de Desenvolvimento Científico e Tecnológico (CNPq), to Empresa Brasileira de Pesquisa Agropecuária (Embrapa), and to Fundação de Amparo à Pesquisa do Estado de Minas Gerais (Fapemig), for financial support.

\section{References}

BAETENS, K.; HO, Q.T.; NUYTTENS, D.; DE SCHAMPHELEIRE, M.; ENDALEW, A.M.; HERTOG, M.L.A.T.M.; NICOLAÏ, B.; RAMON, H.; VERBOVEN, P. A validated 2-D diffusion-advection model for prediction of drift from ground boom sprayers. Atmospheric Environment, v.43, p.1674-1682, 2009. DOI: 10.1016/j.atmosenv.2008.12.047.

COMBELLACK, J.H.; WESTERN, N.M.; RICHARDSON, R.G. A comparison of the drift potential of a novel twin fluid nozzle with conventional low volume flat fan nozzles when using a range of adjuvants. Crop Protection, v.15, p.147-152, 1996. DOI: 10.1016/0261-2194(95)00089-5.

COMPANHIA NACIONAL DE ABASTECIMENTO. Acompanhamento da safra brasileira de café - café - safra 2013 - primeira estimativa - janeiro/2013. Brasília: Conab, 2013. 19p. Disponível em: <http://www.conab.gov.br/OlalaCMS/uploads/ arquivos/13_01_09_17_43_49_boletim_cafe_janeiro_2013.pdf $>$. Acesso em: 14 mar. 2013.

CUNHA, J.P.A.R. da. Simulação da deriva de agrotóxicos em diferentes condições de pulverização. Ciência e Agrotecnologia, v.32, p.1616-1621, 2008. DOI: 10.1590/ S1413-70542008000500039.

DE SCHAMPHELEIRE, M.; SPANOGHE, P.; BRUSSELMAN, E.; SONCK, S. Risk assessment of pesticide spray drift damage in Belgium. Crop Protection, v.26, p.602-611, 2007. DOI: 10.1016/j. cropro.2006.05.013.

FAVARIN, J.L.; DOURADO NETO, D.; GARCÍA, A.G.; VILLA-NOVA, N.A.; FAVARIN, M. da G.G.V. Equações para estimativa do índice de área foliar do cafeeiro. Pesquisa Agropecuária Brasileira, v.37, p.769-773, 2002. DOI: 10.1590/ S0100-204X2002000600005.

FERREIRA, D.F. Sisvar: um programa para análises e ensino de estatística. Revista Symposium, v.6, p.36-41, 2008.

FIGUEROA, C.G.; CUNHA, J.P.A.R.; ADELL, P.C.; GARCÍA, E.M. Efecto antideriva de las boquillas de inyección de aire en los tratamientos de cítricos. Levante Agrícola, v.51, p.268-273, 2012.

GANZELMEIER, H.; RAUTMANN, D.; SPANGENBER, G.R.; STRELOKE, M.; HERRMANN, M.; WENZELBURGER, H.-J.; WALTER, H.-F. Studies on the spray drift of plant protection products: results of a test program carried out throughout the Federal Republic of Germany. Berlin: Blackwell, 1995. 111p.

HOLTERMAN, H.J.; ZANDE, J.C. van de. IMAG Drift Calculator v1.1: user manual. 2003. Available at: $<\mathrm{http} / /$ www.pesticidemodels.eu/sites/www.pesticidemodels.eu/files/ documents/IDCmanual.pdf $>$. Access on: 23 May 2013.

INTERNATIONAL ORGANIZATION FOR STANDARDIZATION. ISO/FDIS 22866: equipment for crop protection - methods for field measurement of spray drift. Geneva: ISO, 2005. 22p.

LEBEAU, F.; VERSTRAETE, C.; STAINIER, M.; DESTAIN, F. RTDrift: a real time model for estimating spray drift from ground applications. Computers and Eletronics in Agriculture, v.77, p.161-174, 2011. DOI: 10.1016/j.compag.2011.04.009. 
MELI, S.M.; RENDA, A.; NICELLI, M.; CAPRI, E. Studies on pesticide spray drift in a Mediterranean citrus area. Agronomie, v.23, p.667-672, 2003. DOI: 10.1051/agro:2003044.

NUYTTENS, D.; DE SCHAMPHELEIRE, M.; BAETENS, K.; BRUSSELMAN, E.; DEKEYSER, D.; VERBOVEN, P. Drift from field crop sprayers using an integrated approach: results of a five-year study. Transactions of the ASABE, v.54, p.403-408, 2011. DOI: $10.13031 / 2013.36442$.

RODRIGUES, G.J.; TEIXEIRA, M.M.; F. FILHO, E.I.; PICANÇO, M.C. Características do fluxo de ar de um pulverizador hidropneumático para aplicação de agroquímicos em plantas arbustivas. Engenharia na Agricultura, v.16, p.199-207, 2008.

SCRAMIN, S.; CHAIM, A.; PESSOA, M.C.P.Y.; FERRACINI, V.L.; PAVAN, L.A.; ALVARENGA, N. Avaliação de bicos de pulverização de agrotóxicos na cultura do algodão. Revista de Ecotoxicologia e Meio Ambiente, v.12, p.43-50, 2002.

TSAI, M.; ELGETHUN, K.; RAMAPRASAD, J.; YOST, M.G.; FELSOT, A.S.; HEBERT, V.R.; FENSKE, R.A. The Washington aerial spray drift study: modeling pesticide spray drift deposition from an aerial application. Atmospheric Environment, v.39, p.6194-6203, 2005. DOI: 10.1016/j.atmosenv.2005.07.011.

VISCHETTI, C.; CARDINALI, A.; MONACI, E.; NICELLI, M.; FERRARI, F.; TREVISAN, M.; CAPRI, E. Measures to reduce pesticide spray drift in a small aquatic ecosystem in vineyard estate. Science of the Total Environment, v.389, p.497-502, 2008. DOI: 10.1016/j.scitotenv.2007.09.019.

WANG, M.; RAUTMANN, D. A simple probabilistic estimation of spray drift - factors determining spray drift and development of a model. Environmental Toxicology and Chemistry, v.27, p.2617-2626, 2008. DOI: 10.1897/08-109.1.

WOLF, D.D.; SMITH, E.S. Uniformity of seed and fertilizer distribution with a hand-operated spinning spreader. Transactions of the ASAE, v.22, p.761-762, 1979. DOI: 10.13031/2013.35097.

YARPUZ-BOZDOGAN, N.; BOZDOGAN, A.M. Comparisons of field and model percentage drift using different types of hydraulic nozzles in pesticide applications. International Journal of Environmental Science and Technology, v.6, p.191-196, 2009. DOI: $10.1007 / \mathrm{BF} 03327621$.

Received on November 16, 2013 and accepted on July 30, 2014 